\title{
Rooting of black raspberry with plant growth regulator
}

\author{
Fabíola Villa ${ }^{*}$ Diego Ricardo Stumm $^{1}$ Daniel Fernandes da Silva ${ }^{1}$ \\ Fernanda Jaqueline Menegusso ${ }^{1}$ Giovana Ritter ${ }^{1}$ Taís Regina Kohler ${ }^{1}$
}

${ }^{1}$ Universidade Estadual do Oeste do Paraná (Unioeste), 85960-000, Marechal Cândido Rondon, PR, Brasil. E-mail: fvilla2003@hotmail.com. "Corresponding author.

\begin{abstract}
The framboseira-negra has a potential for cultivation in Brazil, due to the fact that this fruit produces high quantities of fruits, which confer a high quality jelly. However, their propagation is an obstacle to the establishment of commercial plantations. Production and expansion of a fruit is directly linked to the propagation method and the quality of its development. Given the above, the aim of the present study was to evaluate the use of stem cuttings and IBA in asexual propagation of black raspberry. Two experiments being conducted in greenhouse conditions were performed. Stem cuttings were taken from didactic orchard, with matrix plant of four years, which were the experiments. The first experiment was carried out in factorial $3 \times 2$, with cuttings taken from three regions of the plant branch matrix (apical, median and basal) $x$ two treatments with IBA (without IBA and 2000mg $L^{-1} I B A$ ), containing four repetitions and fifteen cuttings per repetition. The second experiment consisted of a $4 \times 2$, with four sizes of cuttings $\left(5,10,15\right.$ and 20cm) $x$ two treatments with IBA (without IBA and 2000mg $L^{-1} I B A$ ), with four replications and fifteen cuttings by repetition. After eighty days, the percentage of rooted cuttings (\%), average number of roots and shoots for cuttings, the longest root length $(\mathrm{cm})$ and fresh and dry biomass of shoots $(\mathrm{g})$ were assessed. Best results in the formation of root system were observed in middle and apical stem cuttings. Stem Cuttings between 10 and $20 \mathrm{~cm}$ obtained better results for rooting. There is no need to use IBA rooting of cuttings of black raspberry.
\end{abstract}

Key words: Rubus niveus Thunberg, stem cutting, IBA, rooting.

Enraizamento de estacas caulinares da framboeseira-negra com o uso de fitormônios

RESUMO: A framboseira-negra possui potencial de cultivo no Brasil pelo fato dessa fruteira produzir altas quantidades de frutos que conferem uma geleia de alta qualidade. No entanto, a sua propagação é um entrave no estabelecimento de plantios comerciais. Diante do exposto, objetivou-se, com o presente trabalho, avaliar a utilização da estaquia caulinar e ácido indolbutírico na propagação assexuada de framboeseira-negra. Foram realizados dois experimentos, sendo conduzidos em condições de telado. Estacas caulinares foram retiradas de pomar didático de plantas matrizes de quatro anos, as quais constituíram os experimentos. O primeiro experimento foi elaborado em esquema fatorial 3x2, sendo as estacas retiradas de três regiões do ramo da planta matriz (apical, mediana e basal) $x$ dois tratamentos com ácido indolbutírico (sem AIB e 2000mg $L^{-I}$ de AIB), contendo quatro repetições e quinze estacas por repetição. O segundo experimento constituiu-se de esquema fatorial $4 x 2$, sendo quatro tamanhos de estacas $(5,10,15$ e 20cm) x dois tratamentos com ácido indolbutírico (sem AIB e 2000mg $L^{-1}$ de AIB), contendo quatro repetições e quinze estacas por repetição. Após oitenta dias, avaliaram-se a percentagem de estacas enraizadas (\%); número médio de raizes e de brotações por estacas; comprimento da maior raiz (cm) e biomassa fresca e seca das brotações (g). Melhores resultados na formação do sistema radicular foram observados em estacas caulinares medianas e apicais. Estacas caulinares entre $10 \mathrm{e}$ $20 \mathrm{~cm}$ obtiveram melhores resultados para enraizamento. Não há necessidade de utilização de AIB no enraizamento de estacas caulinares de framboeseira-negra.

Palavras-chave: Rubus niveus Thunberg, estaca caulinar, ácido indolbutírico, enraizamento.

\section{INTRODUCTION}

Black raspberry is a fruit shrub from temperate climates that has whitish stems with thorns and can adapt to Brazilian regions with a mild climate and moderate temperatures (SILVA et al., 2012). This shrub produces up to $2.7 \mathrm{~kg}$ of fruit per plant each cycle, which can result in a yield of 18 ton $\mathrm{ha}^{-1}$ (MOURA et al., 2012).

Black raspberry has flowers arranged in terminal panicles and fruits that are small, occur in clusters, and are attractive due to their dark purple color. Black raspberry deserves attention due to its hardiness and high productivity in locations where it 
grows. These small fruits exhibit excellent nutritional characteristics; in particular, these fruits contain more than twice the anthocyanins reported in blackberry and red raspberry fruits (JIN et al., 2008).

In Brazil, black raspberry is distributed throughout the Atlantic Forest and Mantiqueira Mountains. In southern Brazil, Rubus spp. are grown in the states of Santa Catarina, Rio Grande do Sul and Paraná, with emphasis on the production of blackberries and red raspberries (TADEU et al., 2012). Most agricultural activity in the western regions of the state of Paraná consists of grain production and the cultivation of annual plants. Small fruit cultivation can; therefore, be an alternative source of income in family-based agriculture that offers food diversification and increased economic development. Such cultivation is promoted by studies, which aimed to improve the adaptation of fruit species to this region; at present, these species remain scarce.

Asexual propagation of species in the genus Rubus is virtually performed via tissue culture (VILLA et al., 2008) and stem (VILLA et al., 2003) and root cuttings due to the simplicity of processing and handling cuttings and the presence of large quantities of thorns on stems (DIAS et al., 2011). However, in contrast to red raspberry, yellow raspberry, and blackberry, black raspberry produces few buds from roots. For black raspberry, the use of herbaceous and woody stem cuttings is a viable alternative for asexual propagation; the large quantities of material resulting from pruning can be utilized for this purpose (MACEDO et al., 2012).

Cutting is a rapid and inexpensive method of asexual propagation that allows the retention of plant characteristics of agricultural interest and avoids species mixing (HARTMANN et al., 2011). For many semi-woody and herbaceous species, better rooting has been observed for shoot cuttings than for cuttings from other plant parts. However, viability of cuttings depends on rooting capacity, root quality, and favorable conditions for plant development (FACHINELLO et al., 2005; VILLA et al., 2017).

Various external and internal factors may affect rooting, such as genotype, mother plant physiological conditions, environmental conditions, cutting type, cutting position, and auxin treatment of cuttings (ANDRADE et al., 2007). Among auxins, indolebutyric acid (IBA) is a photostable auxin commonly used to promote the rooting of fruit species (HAN et al., 2009).

Conflicting results on the use of IBA have been observed for Rubus plants. A rooting study of root and semi-woody stem cuttings of red raspberry indicated that IBA was not necessary for the rooting of root cuttings (PATTO et al., 2013).
However, more in-depth studies of handling, production and propagation techniques for black raspberry cultivation in subtropical climate regions are needed. The aim of the present study was to evaluate the use of stem cuttings and IBA for the asexual propagation of black raspberry.

\section{MATERIALS AND METHODS}

Cuttings were obtained from material from the summer pruning of four-year-old mother plants performed in February 2015. The cuttings were placed to root under screens in masonry flower beds containing fine sand washed and sterilized with sodium hypochlorite. Sprinkler irrigation was applied every half hour during the day and every hour during the night.

A randomized block design was used for two experiments. For the first experiment, a $3 \times 2$ factorial scheme was utilized, with four replicates and 15 cuttings per replicate. The tested factors were three cutting positions from the mother plant (apical, middle, and basal) and two IBA treatments $(2000 \mathrm{mg}$ $\mathrm{L}^{-1}$ IBA and without IBA). For the second experiment, a $4 \times 2$ factorial scheme was used, with four replicates and 15 cuttings per replicate. The factors tested were four cutting sizes $(5,10,15$, and $20 \mathrm{~cm})$ and two IBA treatments (2000 $\mathrm{mg} \mathrm{L}^{-1} \mathrm{IBA}$ and without IBA).

IBA (a rooting hormone) was applied by dipping the base of a cutting in a water-alcohol IBA solution for 20 seconds. Treated cuttings were then placed to root together with cuttings that had not been treated with IBA.

After 80 days, the percentage of rooted cuttings (\%), average numbers of roots and buds per cutting, length of the largest root $(\mathrm{cm})$, and fresh and dry bud weights $(\mathrm{g})$ were evaluated. The data were subjected to analysis of variance performed using Sisvar software (FERREIRA, 2011). Average values obtained for each cutting position, cutting size, and IBA treatment were compared using a Tukey test with a threshold for significance of $\mathrm{p} \leq 0.05$.

\section{RESULTS AND DISCUSSION}

\section{Experiment 1}

According to the analysis of variance, for the number of roots, length of the largest root, length of fresh and dry biomass of shoots was not significant. For the other factors studied, no significant interaction was observed in relation to the picking region and the use of indolebutyric acid (IBA).

Table 1 shows the percentage of rooted cuttings in terms of their types and use of IBA. Better 
Table 1 - Percentage of stem cuttings of black raspberry rooted in relation to the cutting types and use of IBA. Unioeste, Campus Marechal Cândido Rondon, PR, 2017.

\begin{tabular}{lc}
\hline Stem cutting type & Rooted stem cutting percentage $(\%)$ \\
\hline Apical & $48.33 \mathrm{a}^{*}$ \\
Meddle & $51.67 \mathrm{a}$ \\
Basal & $11.67 \mathrm{~b}$ \\
CV $(\%)$ & 32.41 \\
Use of IBA $\left(2000 \mathrm{mgL}^{-1}\right)$ & Rooted stem cutting percentage $(\%)$ \\
Without AIB & $52.22 \mathrm{a}$ \\
With AIB & $22.22 \mathrm{~b}$ \\
CV $(\%)$ & 32.41 \\
\hline
\end{tabular}

*Lowercase letters differ from each other in the column, by Tukey's test, at 5\% probability of error.

results in the formation of the root system were observed in apical and median stakes, and without auxin use. The necessity of not using the growth regulator for the formation of the root system can be related to the endogenous concentration of auxins in the cuttings already being at favorable levels in relation to the rooting. Thus, the fact that IBA treatment is not necessary for root formation in this study may be related to the cuttings exhibiting endogenous auxin concentrations at favorable levels for rooting.

Application of appropriate plant hormone concentrations to the base of cuttings is extremely important for asexual propagation via cuttings, and optimal concentrations vary across fruit species (HARTMANN et al., 2011). For many plant species, research has indicated that rooting is only possible if cuttings have been dipped into plant hormones. However, plant hormone application may inhibit rooting in certain cases, as has been observed for fig tree (PIO et al., 2006), blackberry (MOREIRA et al., 2012), and raspberry (TIBERTI et al., 2015).

In general, in fruit species, the choices of branch and cutting position from the mother plant result in wide variations in the rooting of cuttings and subsequent seedling development (LIMA et al., 2006). In this study, the percentage of rooting was lower for basal black raspberry cuttings than for middle and apical black raspberry cuttings. This result may be related to factors intrinsic to the plant material used, such as cutting type, time of collection, plant hormones, and tissue age (PAULETTI et al., 2010).

Numbers of buds for different types of cuttings, with and without IBA application, are presented in table 2. Relative to other cuttings, basal cuttings exhibited more buds, with an average of 1.34 buds/plant. This result may be attributable to the accumulation of higher reserves in these cuttings. Basal cuttings also presented better rooting without IBA application.

\section{Experiment 2}

A significant interaction was observed between the number of roots per cutting and mean root length. Both of these parameters were the highest for cuttings with lengths of 10 and $20 \mathrm{~cm}$ in the absence of IBA application (Table 3).

Number of buds and percentage of rooted cuttings were higher for cuttings 15 and $20 \mathrm{~cm}$ in length than for other cuttings and higher without IBA application than with IBA application. No significant interactions between factors were observed, colaboring to TIBERTI et al. (2012), in agreement with the results from a study of vegetative propagation of a blackberry $\times$ raspberry hybrid in

Table 2 - Shoot number of stem cuttings of black raspberry in relation to the cutting types and use of IBA. Unioeste, Campus Marechal Cândido Rondon, PR. 2017.

\begin{tabular}{lc}
\hline Stem cutting type & Shoot number \\
\hline Apical & $0.70 \mathrm{c}^{*}$ \\
Meddle & $1,07 \mathrm{~b}$ \\
Basal & $1.34 \mathrm{a}$ \\
CV $(\%)$ & 19.66 \\
Use of IBA $\left(2000 \mathrm{mgL}^{-1}\right)$ & Shoot number \\
Without AIB & $1.18 \mathrm{a}$ \\
With AIB & $0.90 \mathrm{~b}$ \\
CV $(\%)$ & 19.66 \\
\hline
\end{tabular}

*Lowercase letters differ from each other in the column, by Tukey's test, at $5 \%$ probability of error. 
Table 3 - Number of root per stem cutting and average length of the largest root of black raspberry, in relation to cutting length and use of IBA. Unioeste, Campus Marechal Cândido Rondon, PR. 2017.

\begin{tabular}{|c|c|c|c|}
\hline & Cutting length $(\mathrm{cm})$ & Without IBA & With IBA (2000mg L $\left.{ }^{-1}\right)$ \\
\hline \multirow[t]{5}{*}{ Number of root per cutting } & 5 & $3.55 \mathrm{Aa}^{*}$ & $0.71 \mathrm{Bc}$ \\
\hline & 10 & 5.19Aa & $2.48 \mathrm{Bb}$ \\
\hline & 15 & $3.90 \mathrm{Aa}$ & 5.39Aa \\
\hline & 20 & 4.47Aa & $4,56 \mathrm{Aa}$ \\
\hline & CV (\%) & & \\
\hline \multirow[t]{5}{*}{ Average length of the largest root $(\mathrm{cm})$} & 5 & $9.52 \mathrm{Ab}$ & - \\
\hline & 10 & $15.44 \mathrm{Aa}$ & $2.50 \mathrm{Bb}$ \\
\hline & 15 & $12.08 \mathrm{Ab}$ & $10.80 \mathrm{Aa}$ \\
\hline & 20 & $13.27 \mathrm{Aa}$ & $12.23 \mathrm{Aa}$ \\
\hline & CV (\%) & & \\
\hline
\end{tabular}

*Means followed by the same uppercase letter in the line and lowercase in the column do not differ by Tukey's test, at $5 \%$ probability of error.

which cuttings with a length of $15 \mathrm{~cm}$ were observed to root better without the application of IBA.

Larger and longer cuttings have larger reserves, which are used for bud and root outgrowth (RIOS et al., 2012). Presence of leaves also greatly affects bud outgrowth by cuttings because leaves produce photoassimilates (namely, soluble sugars) that are essential energy sources for bud formation (DIAS et al., 2011).

Few reports have described studies of asexual propagation of black raspberry, and further investigations are needed, particularly research that addresses methods of cutting propagation, time of cutting collection, and regions of cultivation.

\section{CONCLUSION}

In this study, strong root formation was observed for middle and apical stem cuttings and for stem cuttings between 10 and $20 \mathrm{~cm}$ in length. IBA application is not necessary for rooting of stem cuttings from black raspberry.

\section{ACKNOWLEDGEMENTS}

To the Conselho Nacional de Desenvolvimento Científico e Tecnológico $(\mathrm{CNPq})$ for financial support.

\section{REFERENCES}

ANDRADE, R. A. et al. Propagation of the blackberry by cutting using indolbutitic acid. Caatinga, v. 20, n. 2, p. 79-83, 2007. Available from: $<$ http://periodicos.ufersa.edu.br/revistas/index.php/sistema/article/ viewFile/315/117>. Accessed: Nov. 10, 2016.
DIAS, J. P. T. et al. Rooting of shoot cuttings derived of root cuttings of blackberry. Revista Brasileira de Fruticultura, v. esp., n. 1, p. 649653, 2011. Available from: $<$ http://www.scielo.br/scielo.php?script $=$ sci arttext\&pid=S0100-29452011000500090\&lng=en\&nrm $=$ iso $>$. Accessed: Nov. 14, 2016. doi: 10.1590/S0100-29452011000500090.

FACHINELLO, J. C. et al. Propagação de plantas frutíferas. Brasília: Embrapa Informação Tecnológica, 2005. 221p.

FERREIRA, D. F. Sisvar: a computer statistical analysis system. Ciência \& Agrotecnologia, v. 35, n. 6, p. 1039-1042, 2011. Available from: <http://www.scielo.br/scielo.php?script=sci_arttext\&pid=S141370542011000600001\&lng=en\&nrm=iso $>$. Accessed: Sept. 20, 2016. doi: $10.1590 /$ S1413-70542011000600001.

HAN, H. et al. A review on the molecular mechanism of plants rooting modulated by auxin. African Journal of Biotechnology, v. 8, n. 3, p. 348-353, 2009. Available from: < http://www.ajol.info/ index.php/ajb/article/view/59811/0>. Accessed: Aug. 17, 2016.

HARTMANN, H. T. et al. Plant propagation: principles and practices. 8.ed. New York: Englewood Clipps, 880p. 2011.

JIN, C. et al. Ethnobotanical studies on wild edible fruits in southern Yunnan: folk names, nutritional value and uses. Economic Botany, v. 53, n. 1, p. 2-14, 2008. Available from: <http://agris.fao.org/agrissearch/search.do?recordID=US2000106518>. Accessed: May 05, 2016. doi: 10.1007/BF02860785.

LIMA et al. Size and part of the branch to be used as barbados cherry cuttings. Revista Brasileira de Fruticultura, v. 28, n. 1, p. 83-86, 2006. Available from: <http://www.scielo.br/pdf/rbf/v28n1/29698. pdf $>$. Accessed: Oct. 18, 2016.

MACEDO, T. A. et al. Development of plants of two cultivars of raspberry obtained by root cuttings. Revista de Ciências Agroveterinárias, v. 11, n. 2, p. 158-161, 2012. Available from: <revistas.udesc.br/index.php/agroveterinaria/ article/download/5248/3459.pdf $>$. Accessed: Sept. 22, 2016.

MOREIRA, R. A. et al. Indolbutiric acid and hydrogel polymer in the rooting of blackberry. Scientia Agraria Paranaensis, v. 11, n. 1, 
p. 74-81, 2012. Available from: <http://e-revista.unioeste.br/index. php/scientiaagraria/article/view/4435>. Accessed: Aug. 22, 2016. doi: 10.1818/sap.v11i1.4435.

MOURA, P. H. A. et al. Phenology and yield of raspberry cultivars in subtropical regions in Brazil. Pesquisa Agropecuária Brasileira, v. 47, n. 12, p. 1714-1721, 2012. Available from: <http://www.scielo. br/scielo.php?script=sci_arttext\&pid=S0100-204X2012001200006>. Accessed: Aug. 22, 2016. doi: 10.1590/S0100-204X2012001200006.

PATTO, L. S. et al. Vegetative propagation of redberry using refrigeration, IBA and BAP. Revista Ciência Agrária, v. 56, n. Supl., p. 140-144, 2013. Available from: <https://periodicos.ufra edu.br/index.php?journal $=$ ajaes \&page $=$ article \&op $=$ view\&path $\% 5 B$ $\% 5 \mathrm{D}=1441>$. Accessed: Nov. 04, 2016. doi: 10.4322/rca.2013.094.

PAULETTI, D. R. et al. Rooting of nodal segments of fig tree Bragantia, v. 69 , n. 4, p. $877-881$, 2010. Available from: <http:/ www.scielo.br/scielo.php?script $=$ sci_arttext\&pid $=S 0006$ $87052010000400013 \& \operatorname{lng}=$ en\&nrm=iso $>$. Accessed: Nov. 14, 2016. doi: $10.1590 /$ S0006-87052010000400013.

PIO, R. et al. Propagation of fig tree apical cuttings: Different ambient, indolbutyric acid and type. Ciência \& Agrotecnologia, v. 30, n. 5, p. 1021-1026, 2006. Available from: <http://www.scielo. br/pdf/cagro/v30n5/v30n5a30.pdf $>$. Accessed: Jul. 20, 2016.

RIOS, E. S. et al. Concentrations of indole butyric acid, length of time collection of cuttings, propagation of umbu. Revista Caatinga, v. 25, n. 1, p. 52-57, 2012. Available from: $<$ http://periodicos.ufersa edu.br/revistas/index.php/sistema/article/viewFile/2113/pdf $>$. Accessed: Oct. 26, 2016.

SILVA, K. N. et al. Seedling production of black raspberry by different methods of vegetative propagation. Ciência Rural, v. 42, n. 3, p. 418422, 2012. Available from: $<\mathrm{http} / / \mathrm{www} . \mathrm{scielo}$.br/scielo.php?script=sci arttext\&pid $=\mathrm{S} 0103-84782012000300006 \& \operatorname{lng}=\mathrm{en} \& \mathrm{nrm}=\mathrm{iso}>$. Accessed: Nov. 14, 2016. doi: 10.1590/S0103-84782012000300006.
TADEU, M.H. et al. Rooting of stems and root cuttings of Rubus fruticosus using IBA. Revista Ceres, v. 59, n.6, p. 881-884, 2012. Available from: $<$ http://www.scielo.br/scielo.php?script $=$ sci arttext\&pid=S0034-737X2012000600021\&lng=en\&nrm=iso $>$. Accessed: Sept. 29, 2016. doi: 10.1590/S0034-737X2012000600021.

TIBERTI, A. S. et al. 'Boysenberry' propagation by cutting and layering. Ciência Rural, v. 42, n. 3, p. 423-428, 2012. Available from: $<$ http://www.scielo.br/scielo.php?script=sci_arttext\&pid=S010384782012000300007\&lng=en\&nrm=iso >. Accessed: Jul. 19, 2016. doi: http://dx.doi.org/10.1590/S0103-84782012000300007.

TIBERTI, A. S. et al. Cold storage and treatment with plant growth regulators in rooting of root and stems cutting of raspberry. Ciência Rural, v. 45 , n. 8 p. 1445-1450, 2015. Available from: $<$ http://www.scielo.br/scielo.php?script=sci_arttext\&pid=S010384782015000801445\&lng=en\&nrm=iso $>$. Accessed: Oct. 23, 2016. doi: 10.1590/0103-8478cr20131502.

VILLA, F. et al. Propagation of blackberry using of woody cutting. Ciência \& Agrotecnologia, v. 27, n. 4, p. 829834, 2003. Available from: <http://www.scielo.br/scielo. php? script $=$ sci_arttext\&pid $=$ S1413-70542003000400013\&lng $=$ pt\&nrm=iso $>$. Accessed: Nov. 12, 2016. doi: 10.1590/S141370542003000400013

VILLA, F. et al. In vitro blackberry growing: effect of growth regulators and cultivar. Ciência \& Agrotecnologia, v. 32, n. 6, p. 1754-1759, 2008. Available from: <http://www.scielo.br/scielo. php? script $=$ sci_arttext\&pid $=$ S $1413-70542008000600012 \& \operatorname{lng}$ $=$ en $\& n r m=$ iso $>$. Accessed: Sept. 21, 2016. doi: 10.1590/S141370542008000600012 .

VILLA, F. et al. Performance of substrates in rooting capacity of olive tree cuttings. Revista de Ciências Agroveterinárias, v. 16, n. 2, p. 95-101, 2017. Available from: <http://www.revistas.udesc. br/index.php/agroveterinaria/article/view/223811711622017095/ pdf>. Accessed: Jun. 24, 2017. doi:.5965/223811711622017095. 